\title{
OECDpublishing
}

\section{EMERGING OPPORTUNITIES IN THE WEST AFRICAN FOOD ECONOMY}

\section{WEST AFRICAN PAPERS}

July 2016 No. 01 



\section{EMERGING OPPORTUNITIES IN THE WEST AFRICAN FOOD ECONOMY}

This paper has been prepared by

THOMAS ALLEN

PHILIPP HEINRIGS

Sahel and West Africa Club Secretariat/OECD 


\section{WEST AFRICAN PAPERS}

The West African Papers series is designed to share studies with a wide audience of specialists, practitioners, decision-makers and the informed public. The series explores the nature, dynamics and characteristics of African social, economic and political transformations from a regional and multidisciplinary perspective. It seeks to stimulate discussion and gather information to better anticipate the changes that will shape future policies. Papers are available in English and/or French, and summaries are available in both languages. Initiated by the Sahel and West Africa Club (SWAC) to highlight and promote West African issues, the work presented is prepared by its Secretariat, Members and partners; other OECD departments; related international organisations; and associated experts.

For more information on the Sahel and West Africa Club: http://www.oecd.org/swac.

Please cite this publication as:

Allen, T. and P. Heinrigs (2016), "Emerging Opportunities in the West African Food Economy", West African Papers, No. 01, OECD Publishing, Paris.

http://dx.doi.org/10.1787/5jlvfj4968jb-en

Author contact: thomas.allen@oecd.org and philipp.heinrigs@oecd.org

ISSN 2414-2026

OECD Working Papers should not be reported as representing the official views of the OECD or of its member countries. The opinions expressed and arguments employed are those of the authors.

This document and any map included herein are without prejudice to the status of or sovereignty over any territory, to the delimitation of international frontiers and boundaries and to the name of any territory, city or area.

Working Papers describe preliminary results or research in progress by the author(s) and are published to stimulate discussion on a broad range of issues on which the OECD works. Comments on Working Papers are welcomed, and may be sent to the Sahel and West Africa Club, OECD, 2 rue André-Pascal, 75775 Paris Cedex 16, France.

Authorised for publication by Laurent Bossard, Director, Sahel and West Africa Club Secretariat (SWAC/OECD).

You can copy, download or print OECD content for your own use, and you can include excerpts from OECD publications, databases and multimedia products in your own documents, presentations, blogs, websites and teaching materials, provided that suitable acknowledgment of OECD as source and copyright owner is given. All requests for commercial use and translation rights should be submitted to rights@oecd.org. 


\begin{abstract}
Driven by urbanisation and income growth, the West African food economy has radically changed over the past 60 years. The food economy, including all activities involved in producing food, from production to processing, transport and distribution totalled USD 178 billion in 2010, equal to 36\% of the regional GDP. Forty percent of the value added in the food economy is generated by non-agricultural activities. Post-harvest activities are rapidly developing and are expected to grow more quickly in coming decades than other segments of the food value chain. Policies and monitoring systems need to adjust to these changes to leverage the emerging opportunities in agricultural development, employment and value creation. This paper estimates the size and structure of this new food economy, and explores major policy implications.
\end{abstract}

Keywords: food systems, food policy, agricultural transformation, processed food, urbanisation, West Africa, value chains

JEL codes: Q18, Q13

\title{
TABLE OF CONTENTS
}

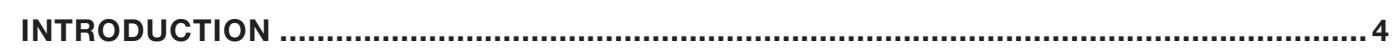

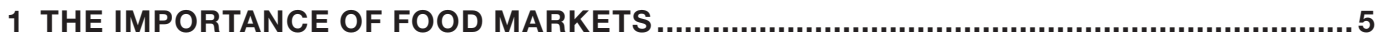

1.1 Urbanisation: The driving force of change ............................................................. 5

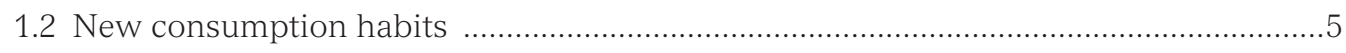

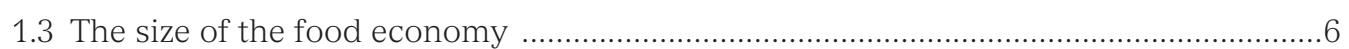

2 AN INCREASINGLY NON-AGRICULTURAL FOOD ECONOMY .................................... 9

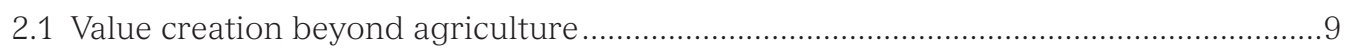

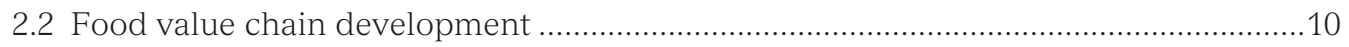

3 POLICY AND FOOD SECURITY IMPLICATIONS........................................................... 14

3.1 Connecting and co-ordinating food economy activities ...........................................14

3.2 Adapting food and nutrition security tools ........................................................ 16

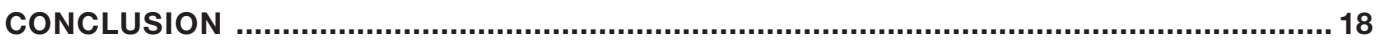

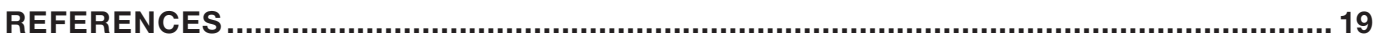




\section{INTRODUCTION}

- trong demographic growth and rapid urbanisation over the past 60 years have $\checkmark$ radically transformed the West African food economy. While the region was largely rural at independence and agricultural activities concentrated in subsistence farming and export cash crop production, $45 \%$ of its population now lives in cities where most food is bought in markets. Using the latest data from expenditure and consumption surveys, this paper estimates the size and structure of the new food economy, and highlights some of the major policy issues arising from it.

- The West African food economy, including all activities involved in producing, processing and distributing food for human consumption, totalled USD 178 billion in 2010, or 36\% of the regional GDP. The food economy is the region's biggest economic sector.

- Urbanisation and urban lifestyles are also accompanied by shifts in dietary patterns, which are spreading beyond the frontiers of towns and cities. More fruits and vegetables and more processed foods are being consumed, while the consumption of cereals and pulses is declining. Processed foods account for 39\% of household food expenditure, and are an important part of food consumption across all income brackets, including low income households.

- Non-agricultural activities of the food economy, such as processing, logistics, transport and retail are developing quickly and already account for $40 \%$ of the sector's value added.

- Post-harvest segments of food value chains and in particular food processing activities, account for a significant share in manufacturing value-added and off-farm employment. Growth in these activities is projected to accelerate further.

Transformations in the food economy are creating new policy challenges. Efforts to improve agricultural production may prove unsuccessful if challenges in the other segments of the value chain are not addressed simultaneously. Availability and access to food are now contingent on a series of activities occurring along value chains and a growing share of urban and rural

The West African food economy totalled 178 USD billion in 2010, or $36 \%$ of the regional GDP. populations depend on this food economy to access food. In this evolving context, food and nutrition security depends on a greater number of factors and is becoming more complex, requiring that policy-making and monitoring systems adapt as a result. 


\section{THE IMPORTANCE OF FOOD MARKETS}

Since 1960, food demand in West Africa has increased fivefold. In 2010 it represented USD 178 billion, over two-thirds of which was traded in markets. Higher value-added products, especially processed products, account for a significant and growing share of the demand. Urbanisation is a driving factor of these fast-paced and profound changes.

\subsection{Urbanisation: The driving force of change}

Between 1950 and 2010, the population of West Africa grew from 73 million to 317 million inhabitants (OECD, 2015). Over the same period, the urban population grew by a factor of 25, from 5 million to 133 million. While no country in 1950, with the exception of Senegal, had a level of urbanisation above 10\%, by 2010 the regional level of urbanisation was 42\% and six countries, including Nigeria, had a level of urbanisation of $45 \%$ or higher. These settlement patterns are shaping the region's economic, social and political landscapes.

Cities are growing in size and number. Urban growth translates into higher concentration of people in the largest cities, but also into the development of a network of small and medium-sized cities. In 1950, the region counted 152 urban agglomerations with more than 10000 inhabitants; in 2010, the region numbered 1947 urban agglomerations, including 22 with more than one million inhabitants. The average distance between urban centres is now one-quarter its previous level, dipping from $111 \mathrm{~km}$ to $30 \mathrm{~km}$. Linked by transportation and communications networks, these cities and towns act as nodes for the spatial organisation of trade and markets. Markets have become households' main source of food supply. Urban growth contributes to the integration of rural areas into the market economy, and is a major driving force in transforming agri-food production systems.

Food market development can be measured against changes in the non-agricultural population. While urbanisation implies that a growing share of urban households no longer takes part in agricultural activities, the same can also be said for rural areas where other services and activities are emerging. With $50 \%$ of the West African population no longer engaged in agricultural activities, food supply channels are changing. In urban areas, households' main food supply is through markets, with an average of more than $90 \%$ of household food expenses provided

Between 1950 and 2010, the urban population grew by a factor of 25 , from 5 million to 133 million. through the various commercial distribution channels (OECD, 2013). In rural areas, the share of market supplies accounted for almost half of the monetary value of food consumption in 2010. At the regional level at least two-thirds of food needs are now met by markets.

\subsection{New consumption habits}

The West African diet is changing as incomes rise and consumer habits evolve with urban lifestyles. Some of the changes in dietary patterns that are associated with changes in living conditions are well-documented and have been observed elsewhere.

First, according to Engel's law, the share of income allocated to food expenditure drops significantly with income growth; accounting for 59\% of income among the poorest households in West Africa and 19\% among the richest households. ${ }^{1}$ Given the size of the poorest populations, the food market is West Africa's largest market. With higher average incomes in cities, urban households allocate $46 \%$ of their total expenditure to food, compared to $60 \%$ in rural areas.

Second, the composition of household food baskets (Figure 1.1) differs significantly by environment; rural dwellers consume proportionally more grains (and grain-based products) than urban dwellers, who consume relatively more fruit, vegetables, meat and

1 Not including catering and meals outside the home. 
fish. This difference is consistent with Bennet's law, where the percentage of starchy foods diminishes as incomes increase. Households are substituting different foods in their diets, turning away from those considered inferior and replacing them with more expensive calories. Dietary diversity is improving and foods higher in protein, such as meat, are making inroads.

\section{Figure 1.1}

Distribution of household food consumption by environment - West Africa (2010)

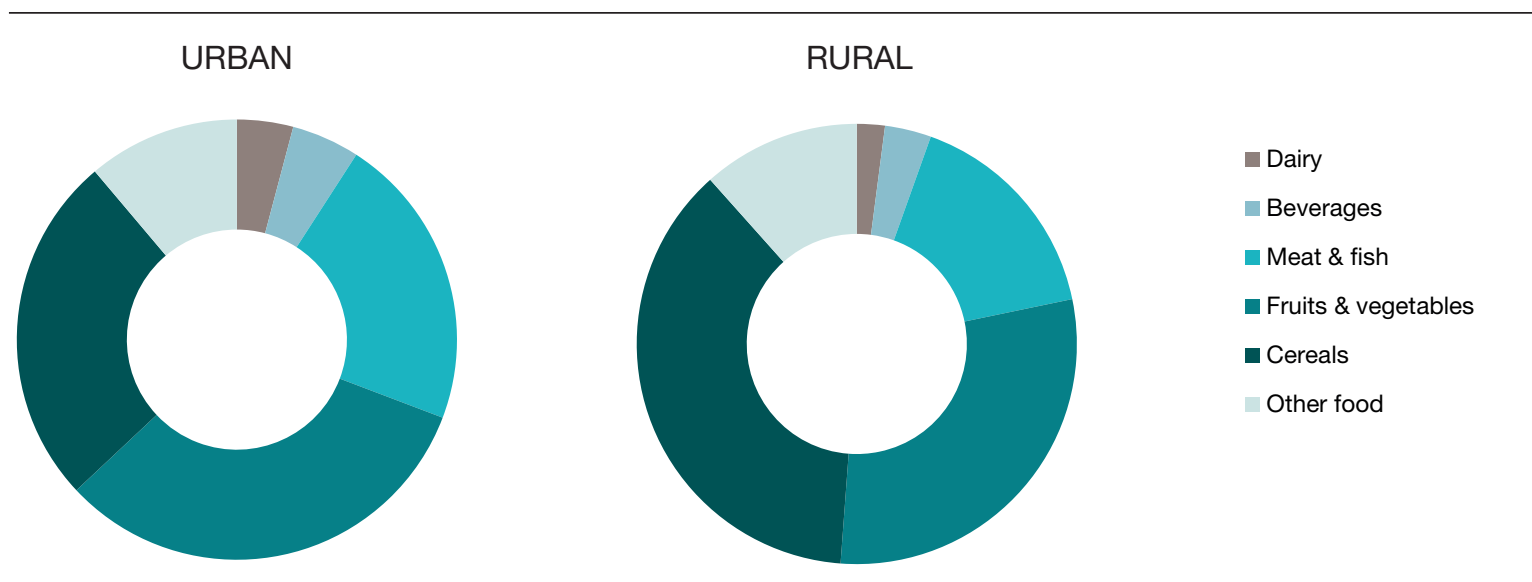

Source: World Bank, 2015 and authors'calculations

The reduction in consumption of grains and especially tropical roots and tubers does not necessarily indicate that these foods are losing importance in agricultural production systems. Rather, it reflects a transition towards new uses. Although direct consumption has declined, these crops are being converted into higher value-added foods, such as meat, or processed products (like attiéké, gari or pasta).

On average, processed products (apart from grains and processed starchy products) account for $39 \%$ of household food consumption (Table 1.1). The share of processed foods is slightly higher in urban food baskets (41\%) than in rural ones (36\%). Similarly, higher income households spend

Processed products account for $39 \%$ of household food consumption. the largest share of food consumption on processed foods (49\%). However, processed products already account for a significant portion of the food baskets in the poorest households (36\%), in both urban and rural areas. The value added included in final food products are increasing as incomes rise, yet at the same time processed foods are consumed at low income levels. This trend has been confirmed by other studies in West Africa (Hollinger and Staatz, 2015) and in southern and eastern Africa (Tschirley et al., 2015).

\subsection{The size of the food economy}

Driven by population growth, urbanisation and rising incomes, the West African food economy is significantly larger than generally believed and is experiencing rapid growth. National accounts data are insufficient to measure the sector's importance. A more precise estimate of its size is now possible for the first time based on consumption and expenditure surveys compiled and aggregated by the World Bank. By isolating food products, the food economy can be calculated as the sum of households' food expenditure. In 2010, it represented USD 178 billion, or 36\% of the regional GDP. The share of total household income spent on food was estimated at $52 \%$ in $2010 .^{2}$

2 Data are available for the entire area covered by SWAC/OECD (Benin, Burkina Faso, Cabo Verde, Côte d'Ivoire, Gambia, Ghana, Guinea, Guinea-Bissau, Liberia, Mali, Mauritania, Niger, Nigeria, Senegal, Sierra Leone, Chad and Togo) except Guinea-Bissau. 
Table 1.1

Share of processed and non-processed foods in household diets by environment and income level - West Africa (2010)

\begin{tabular}{|c|c|c|c|c|c|}
\hline & \multirow{2}{*}{ Income category* } & \multirow{2}{*}{ Beverages } & \multirow{2}{*}{ Cereals $^{\star \star}$} & \multicolumn{2}{|c|}{ Food (excluding cereals \& beverages) } \\
\hline & & & & Unprocessed & Processed ${ }^{\star \star *}$ \\
\hline \multirow{5}{*}{$\begin{array}{l}\text { Total } \\
\text { population }\end{array}$} & Lowest & $4 \%$ & $31 \%$ & $29 \%$ & $36 \%$ \\
\hline & Low & $5 \%$ & $20 \%$ & $32 \%$ & $42 \%$ \\
\hline & Middle & $9 \%$ & $13 \%$ & $31 \%$ & $48 \%$ \\
\hline & Higher & $12 \%$ & $11 \%$ & $28 \%$ & $49 \%$ \\
\hline & All & $4 \%$ & $27 \%$ & $30 \%$ & $39 \%$ \\
\hline \multirow[t]{5}{*}{ Urban } & Lowest & $4 \%$ & $24 \%$ & $35 \%$ & $38 \%$ \\
\hline & Low & $6 \%$ & $18 \%$ & $33 \%$ & $44 \%$ \\
\hline & Middle & $9 \%$ & $13 \%$ & $31 \%$ & $47 \%$ \\
\hline & Higher & $12 \%$ & $11 \%$ & $28 \%$ & $49 \%$ \\
\hline & All & $5 \%$ & $20 \%$ & $33 \%$ & $41 \%$ \\
\hline \multirow[t]{5}{*}{ Rural } & Lowest & $3 \%$ & $37 \%$ & $25 \%$ & $35 \%$ \\
\hline & Low & $5 \%$ & $25 \%$ & $31 \%$ & $39 \%$ \\
\hline & Middle & $7 \%$ & $14 \%$ & $29 \%$ & $50 \%$ \\
\hline & Higher & $12 \%$ & $19 \%$ & $30 \%$ & $38 \%$ \\
\hline & All & $4 \%$ & $34 \%$ & $26 \%$ & $36 \%$ \\
\hline
\end{tabular}

Notes:

*Income categories:

- Lowest—under 2.97 USD per capita/day

- Low-between 2.97 and 8.44 USD per capita/day

- Middle-between 8.44 and 23.03 USD per capita/day

- Higher-above 23.03 USD per capita/day

${ }^{* *}$ All cereals in the form of grain, flour or semolina, including starchy products requiring some processing (for example, manioc).

${ }^{\star * \star}$ Processed products include: dairy products; edible oils; bread, biscuits and pasta; meat, poultry (fresh, frozen or preserved); fish and seafood (dried, smoked or preserved); confectionary and chocolate; conditioned fruit and vegetable based products (jams, honey and concentrates). Cereal products in the form of flour or semolina are not included as processed products because the data used cannot differentiate them from non-processed products.

Source: World Bank, 2015 and authors'calculations

Nigeria accounts for $71.4 \%$ of the total regional food GDP (Figure 1.2). Far behind follow Ghana (8.5\%), Côte d'Ivoire (3.8\%) and Senegal (3.4\%). Nigeria's over-representation compared to its population (51\% of the regional population) reflects its higher per capita income and a different consumption structure. ${ }^{3}$ Nigeria also generates $69 \%$ of the regional agricultural GDP.

The food economy, which includes households' production for own consumption, is shared rather evenly between urban (55\%) and rural (45\%) dwellers. With the regional level of urbanisation in 2010 at 42\%, this implies that urban households spent approximately 50\% more on food per capita than rural households.

The market transactions in the food economy represented USD 126 billion in 2010. Production for own consumption, estimated at $60 \%$ for agricultural households' total consumption ${ }^{4}$, 10\% for non-agricultural households and $30 \%$ at regional level, has been subtracted since it does not involve any transaction. Yet, the size of market transactions

\section{Market transactions in the food economy represented USD 126 billion in 2010.} 3 Fruits and vegetables account for $38 \%$ of Nigerian household food consumption, compared to 23\% elsewhere in West Africa. At the
same time, $68 \%$ of the region's vegetables were produced in Nigeria in 2010 (FAOSTAT, 2015).
4 Based on an estimated 50\% own-consumption in rural households (Bricas and Tchamda, 2015), 25\% in non-agricultural rural
households (OECD, 2013), and 10\% in urban households. 


\section{Figure 1.2}

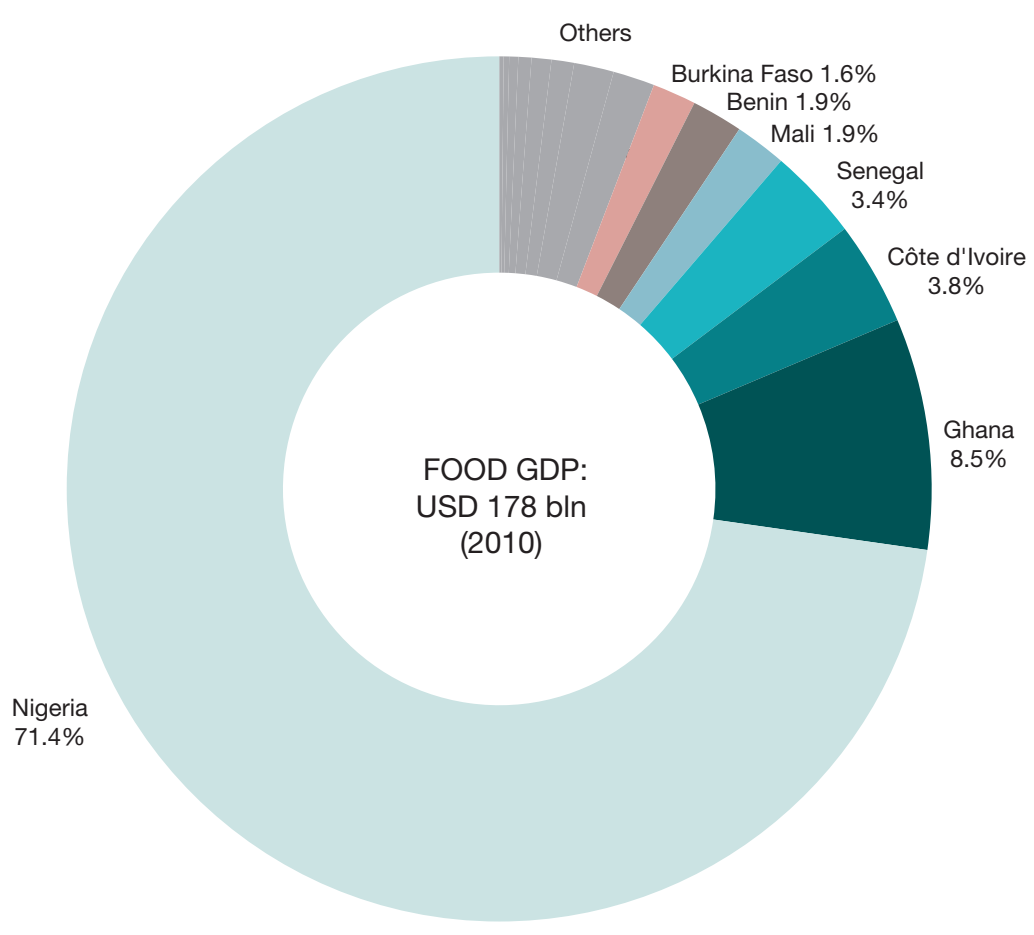

Note : *exprimé en parité de pouvoir d'achat.

Sources: World Bank, 2015; UNSD, 2015 and authors'calculations

that reveal the importance of new activities and actors involved in these transactions, highlights the magnitude of the transformations that West Africa has experienced. The region's food economy went from a subsistence-based economy to a market-economy. In addition, the total size of the food economy also reveals the limited dependence of West Africa on imported foods. Although food imports have increased, they were estimated at USD 12 billion in 2010, or 6.5\% of total domestic demand (USD 178 billion) (FAOSTAT, 2015).

West African agriculture has massively redirected its output towards its regional food market. In 2010, the size of the regional market of non-producing consumers, i.e. consumers relying exclusively on markets for their food supply, represented a volume of 143 trillion $\mathrm{kcal}^{5}$, a 13-fold increase in 60 years. While extra-regional agricultural exports were equal to this segment of the regional market (non-producing consumers) in 1961, they only represented 12\% in 2010 (Figure 1.3). West Africa's food economy has significantly changed from the independence period export-based agricultural economy. Local trade supporting mainly self-sufficient communities has given way to trade over longer distances, connecting cities and rural areas and regions, and cash crop export markets are now a fraction of the size of regional markets. The regional food market now dominates emerging economic opportunities.

5 Monitoring changes according to the volume of products consumed, where kilocalories (kcal) are used as the standard of measure, allows for comparisons to be made of the levels of consumption and the size of markets across countries and time periods, regardless of prices. 
Figure 1.3

Agricultural exports and regional market - West Africa (1961-2010)

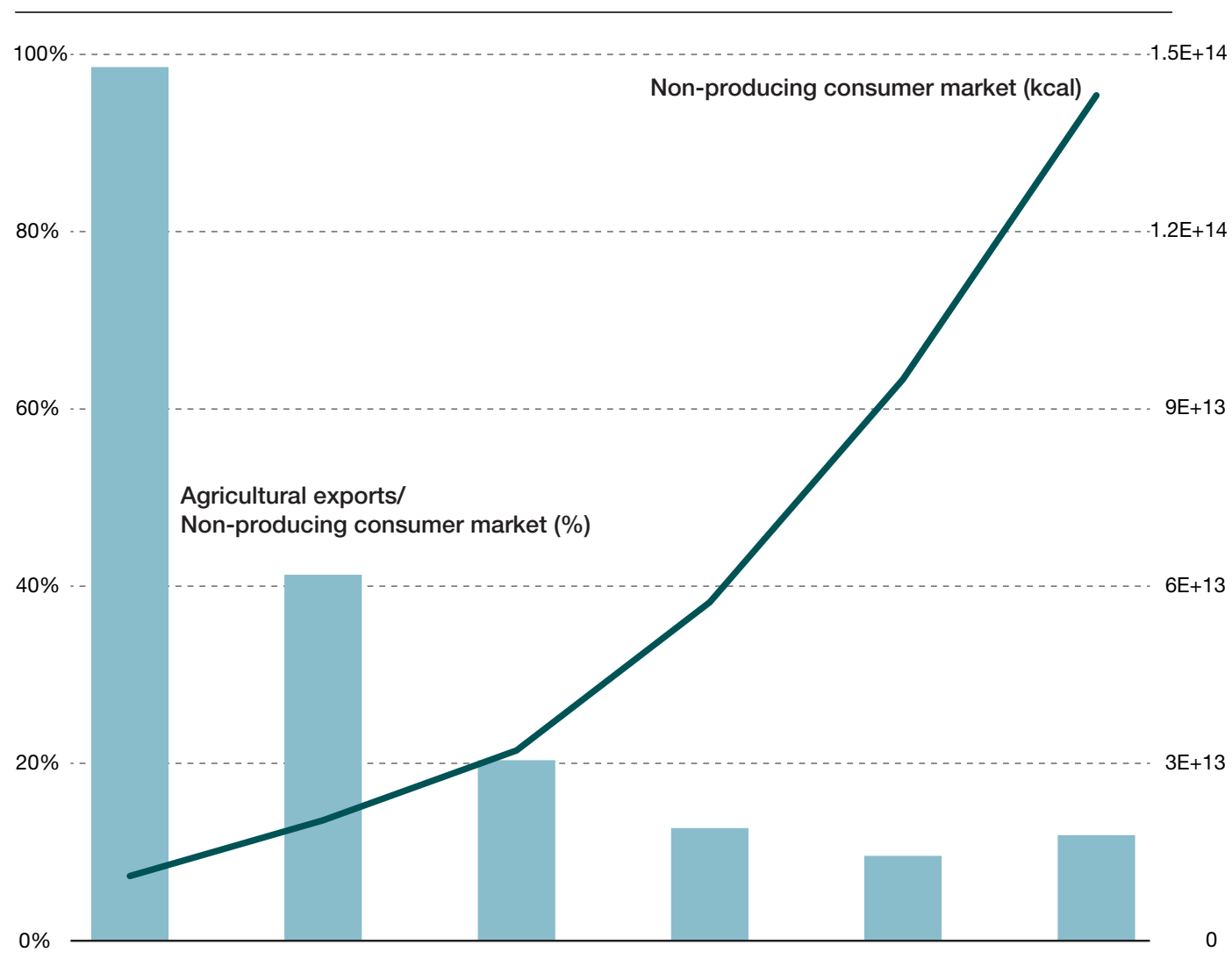

Source: FAOSTAT, 2015 and authors'calculations

\section{AN INCREASINGLY NON-AGRICULTURAL FOOD ECONOMY}

The development of food markets offers new opportunities for value creation and diversification in the food sector. Economic activities upstream (inputs and services) and downstream (marketing and processing) of farm production are thriving. These non-agricultural activities already account for $40 \%$ of the food economy's value added.

\subsection{Value creation beyond agriculture}

The growth and change in dietary patterns is transforming the distribution of value added between agriculture and other sectors of the food economy. Post-harvest activities, from transport to food processing and distribution are gaining importance and the share of agriculture in the food economy is declining.

The ratio between the size of the food economy and agricultural GDP provides a first approximation of the diversification of agri-food activities. It indicates the degree of development of activities related to but distinct from agriculture and the level of structural transformation in the agri-food sector. At the regional level, this ratio is 1.6, indicating that the monetary value of the food economy is $60 \%$ greater than the agricultural GDP (Table 2.1). Agricultural exports were subtracted from the agricultural GDP to allow for an estimation of the diversification of the regional food economy. Since a significant percentage of agricultural GDP is not intended for human consumption such as cotton, wood, etc. ${ }^{6}$, the share of agriculture in the food economy does not exceed $60 \%$. In other words, $40 \%$ of the value added in the food economy is no longer generated by agriculture.

6 Forestry activities are estimated to make up approximately 8\% of the agricultural GDP in sub-Saharan Africa in 2010 (FAOSTAT, 2015). The authors of the Agrimonde report also estimate the share of plant-based food calories used for non-food agricultural crops (NFAC) in sub-Saharan Africa at 5\% and 2\% respectively; seed losses of roughly 10\% must also be included (Paillard et al., 2010). 
The ratio is greater than 1.0 in countries that have the highest GDP per capita and/or the largest food imports, such as Cabo Verde, Ghana, Nigeria or Senegal (Table 2.1). To determine the domestic contribution to household food supply, food imports should be subtracted from the food

$40 \%$ of the value added in the food economy is no longer generated by agriculture.
GDP. With this adjustment, the ratio is 1.5 regionally, indicating that most of the regional demand is locally supplied. These results confirm that food value chains are growing more sophisticated and that post-harvest activities are expanding. Although time-series data is missing to fully characterise the changing structure of the food economy, the share of non-agricultural activities indicates a process of sectoral reorganisation.

\subsection{Food value chain development}

New actors enter the food economy as activities develop outside of agriculture, especially in the post-harvest segments. The organisation and length of the value chains vary and depend on the goods being traded. For perishable goods like vegetables and fruit, chains are short with generally zero to one intermediary between producers and consumers. In contrast, cereal-based processed products, whether 'ready-to-eat' (bread, pancakes, cakes, etc.) or 'ready-to-use' (flour, semolina, granules, etc.), undergo more or less sophisticated processing, stabilisation and conditioning processes before reaching the end consumer. The raw material is bagged, transported, unloaded, stored, controlled, calibrated, cleaned, crushed, laminated and sometimes dried or grilled, frozen or refrigerated, conditioned, packaged, etc. Some of these activities may occur more than once along the supply chain. Generally, market growth and the demand for more processed products drive the development of post-harvest activities, which are not part of the primary sector and which are increasingly performed off the farm and outside the household. They can schematically be grouped into two major segments along the value chains: food processing and distribution (Box 2.1).

Table 2.1

Share of the food economy compared to agricultural activities (2010)

\begin{tabular}{|c|c|c|c|c|}
\hline & $\begin{array}{c}{[1]} \\
\text { F00D GDP/GDP }\end{array}$ & $\begin{array}{c}{[2]} \\
\text { AGRI GDP*/GDP }\end{array}$ & $\begin{array}{c}{[1] /[2]} \\
\text { F00D GDP/AGRI GDP* }\end{array}$ & $\begin{array}{c}{[3]} \\
\text { F00D IMPORT/AGRI GDP* }\end{array}$ \\
\hline Cabo Verde & $31 \%$ & $8 \%$ & 3.9 & 1.3 \\
\hline Senegal & $41 \%$ & $13 \%$ & 3.2 & 0.7 \\
\hline Benin & $43 \%$ & $23 \%$ & 1.8 & 0.3 \\
\hline Guinea & $39 \%$ & $22 \%$ & 1.7 & 0.3 \\
\hline Nigeria & $37 \%$ & $23 \%$ & 1.6 & 0.1 \\
\hline West Africa & $36 \%$ & $23 \%$ & 1.6 & 0.1 \\
\hline Ghana & $35 \%$ & $24 \%$ & 1.5 & 0.1 \\
\hline Mauritania & $29 \%$ & $19 \%$ & 1.5 & 0.4 \\
\hline Gambia & $36 \%$ & $26 \%$ & 1.4 & 0.6 \\
\hline Liberia & $67 \%$ & $46 \%$ & 1.4 & 0.5 \\
\hline Guinea-Bissau & $49 \%$ & $38 \%$ & 1.3 & 0.2 \\
\hline Togo & $39 \%$ & $32 \%$ & 1.2 & 0.2 \\
\hline Niger & $38 \%$ & $38 \%$ & 1 & 0.1 \\
\hline Chad & $18 \%$ & $21 \%$ & 0.9 & 0.1 \\
\hline Mali & $31 \%$ & $34 \%$ & 0.9 & 0.1 \\
\hline Sierra Leone & $40 \%$ & $52 \%$ & 0.8 & 0.1 \\
\hline Burkina Faso & $23 \%$ & $28 \%$ & 0.8 & 0.1 \\
\hline Côte d'Ivoire & $28 \%$ & $\mathrm{n} / \mathrm{a}$ & $\mathrm{n} / \mathrm{a}$ & $\mathrm{n} / \mathrm{a}$ \\
\hline
\end{tabular}

Note: * Adjusted agricultural GDP is equivalent to the agricultural GDP less agricultural exports.

Sources: FAOSTAT, 2015; UNSD, 2015 and authors'calculations 
Box 2.1

Value chains, agribusiness and agro-industries: Definitions and concepts

The United Nations Industrial Development Organization (UNIDO), which uses the term "agri-food value chain", defines value chains as all of the "actors connected along a chain producing and bringing goods and services to end consumers through a complex and sequenced set of activities" (Henriksen et al., 2010).

The Food and Agriculture Organization of the United Nations (FA0) has proposed a definition of agricultural value chains as the "set of actors and activities that bring a basic agricultural product from production in the field to final consumption, where at each stage value is added to the product. A value chain can be a vertical linking or a network between various independent business organisations and can involve processing, packaging, storage, transport and distribution," (FAO, 2010). The terms "agricultural value chain" and "agri-food value chain" can be considered similar. Food value chains may therefore be seen as the sequence of activities whose final objective concerns human nutrition only.
Furthermore, "agribusiness" is commonly defined as "part of a modern economy devoted to the production, processing and distribution of food, fibre products and by-products including the financial institutions that fund these activities" (Encyclopaedia Britannica, 2011). It encompasses i) the producers of inputs intended for agricultural production (seed, fertilizer, etc.); ii) commercial farms; iii) the agro-industry, which includes the Food, Beverage and Tobacco (FBT) sub sector as well as textile, leather or wood, etc.; iv) providers of equipment and machinery for processing agricultural raw materials; v) and lastly, supporting services, including marketing, financing, distribution, transport and packaging (AfDB, 2014).

Agro-industries are a "subset of the manufacturing sector that processes raw materials and intermediate products derived from agriculture, fisheries and forestry" (Henson and Cranfield, 2009). These concepts are illustrated in Figure 2.1.

1 Traduction des auteurs : "Actors connected along a chain producing and bringing goods and services to end consumers through a complex and sequenced set of activities".

2 Traduction des auteurs: "Part of a modern economy devoted to the production, processing and distribution of food, fibre products and by-products including the financial institutions that fund these activities ".

3 Traduction des auteurs : "Subset of the manufacturing sector that processes raw materials and intermediate products derived from agriculture, fisheries and forestry ".

Figure 2.1

Value chains, agribusiness and agro-industries: Definitions and concepts

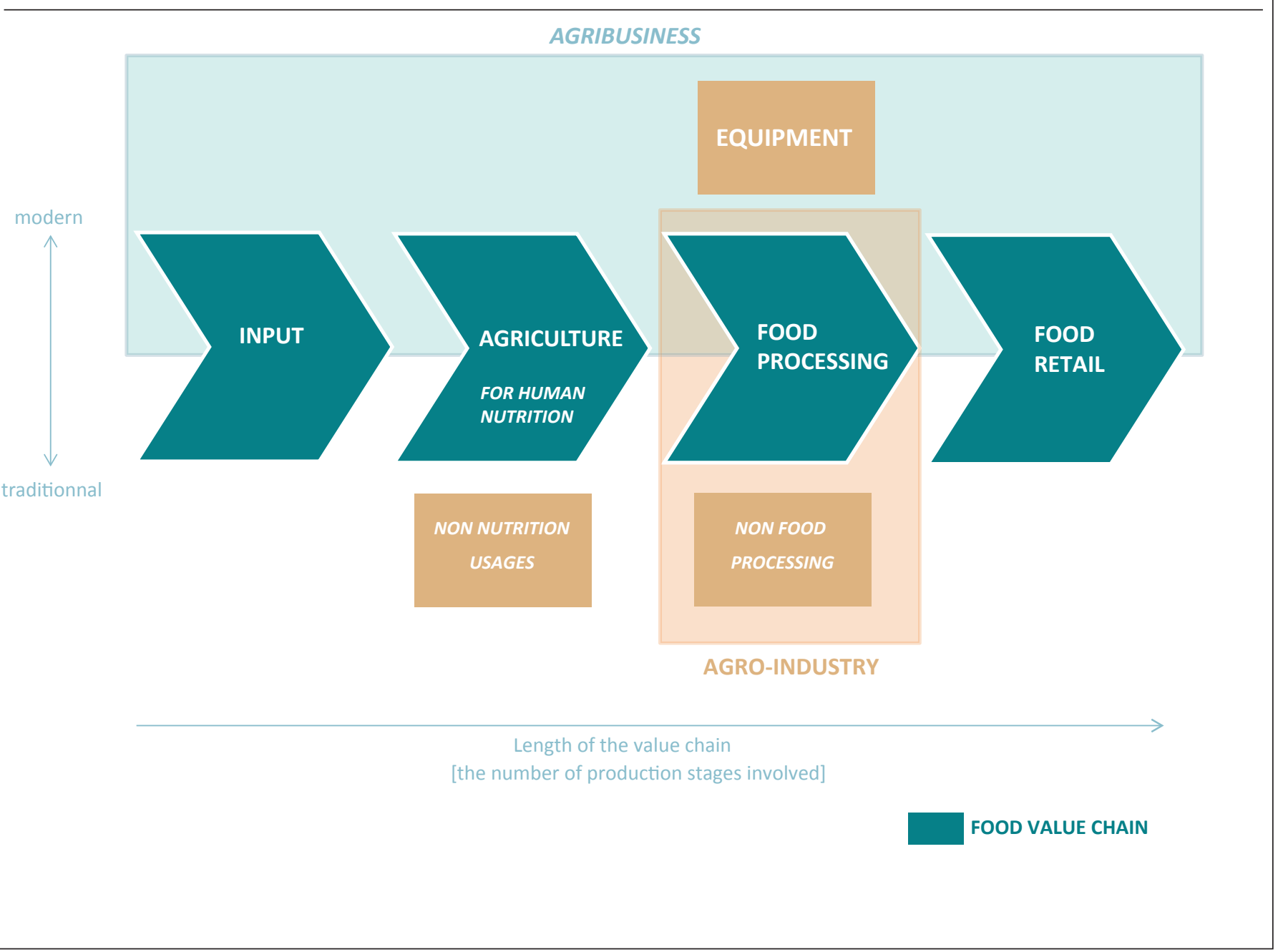


Food processing activities are a recent development in the region and their often informal nature make them difficult to quantify. This segment covers a wide variety of activities and actors at different levels of technological prowess. Apart from a few relatively large industrial structures (breweries, flour mills, etc.), the sector primarily consists of microenterprises and SMEs which are often family operated and informal. Production processes are frequently artisanal, involving limited mechanisation and standardisation. However, some enterprises have evolved into larger, more productive companies supplying the regional market.

Agro-industries are defined as a sub-sector of the manufacturing sector that processes raw agricultural products, including food processing activities. The few available data show that its overall volume of activity has been growing since the 1980s. In Senegal, agro-industry is the largest manufacturing sub-sector, and has grown by $4 \%$ per year since 1980 (Figure 2.2).

Figure 2.2

Manufacturing activities in Senegal (1980-2010)

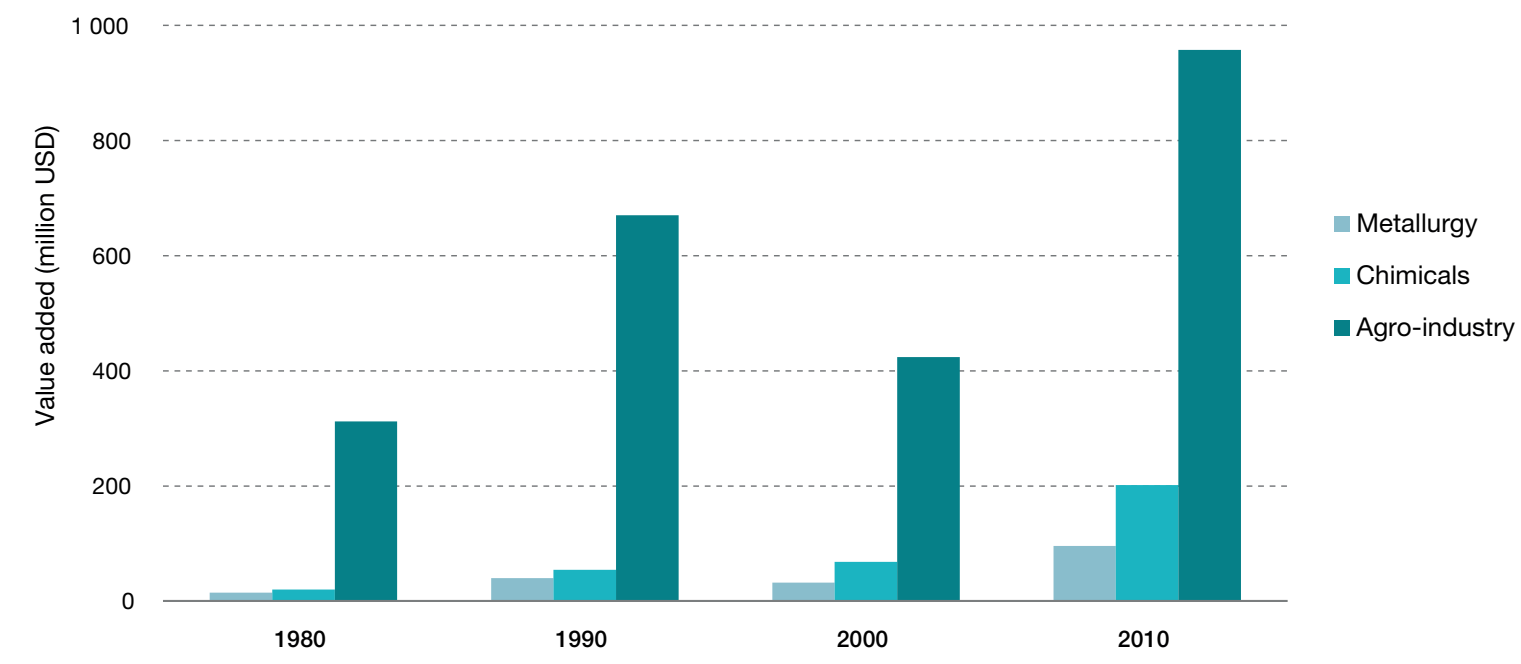

Sources: DPEE Senegal, 2015 and authors' calculations

The food processing industry component of agro-industries has been growing by more than 7\% annually since 2000 in Senegal. In 2010, food processing contributed 37\% of the value added created in the manufacturing sector. However, insufficient data are available to more accurately characterise the structural changes taking place in the agri-food sector.

The distribution segment of food value chains includes collectors, wholesalers, transporters and retailers. Generally, retailers operate in traditional markets, sometimes with stalls or stores, and sometimes through supermarkets in urban areas, and they also include a host of street vendors. The informal sector's role in marketing food stuffs is extremely important. Street food is also growing in popularity, with high demand among urban workers for 'ready-to-eat' foods. These distribution channels are vital to ensure market functioning and household access to food.

The increase and concentration of food demand driven by urbanisation also requires the development of spatial approaches to food distribution channels. With an increasing differentiation between production and consumption zones, management of territories and their connections are becoming imperative for food security. The development of food value chains involves a growing number of activities and actors, which are also connected over larger geographic areas, requiring the development of more complex distribution channels. 
Box 2.2

West Africa's participation in global food value chains

The geographical dispersion of the production process is also observed internationally. Because of a significant reduction in trade costs, food companies today have the opportunity to dispatch production, processing and distribution activities across the world. The fact that these activities are increasingly distributed over different countries explains the concept of global value chains (GVCs).

Analysis of participation indicators reveals that West African countries are connected to food GVCs, but do not all contribute equally. Ghana and
Côte d'Ivoire, for example, are positioned more as buyers of intermediate products ('downstream' or backward participation), while Nigeria is first and foremost a supplier of intermediate products ('upstream' or forward participation). The size of its domestic market is one of the main factors explaining this difference (OECD, 2016). Nigeria can count on its market to source inputs (which reduces its 'downstream' participation), and to produce and export intermediate products (which tends to increase its 'upstream' participation).

\section{Figure 2.3}

Participation in Global Food Value Chains (2011)

\section{Backward Indicator*}

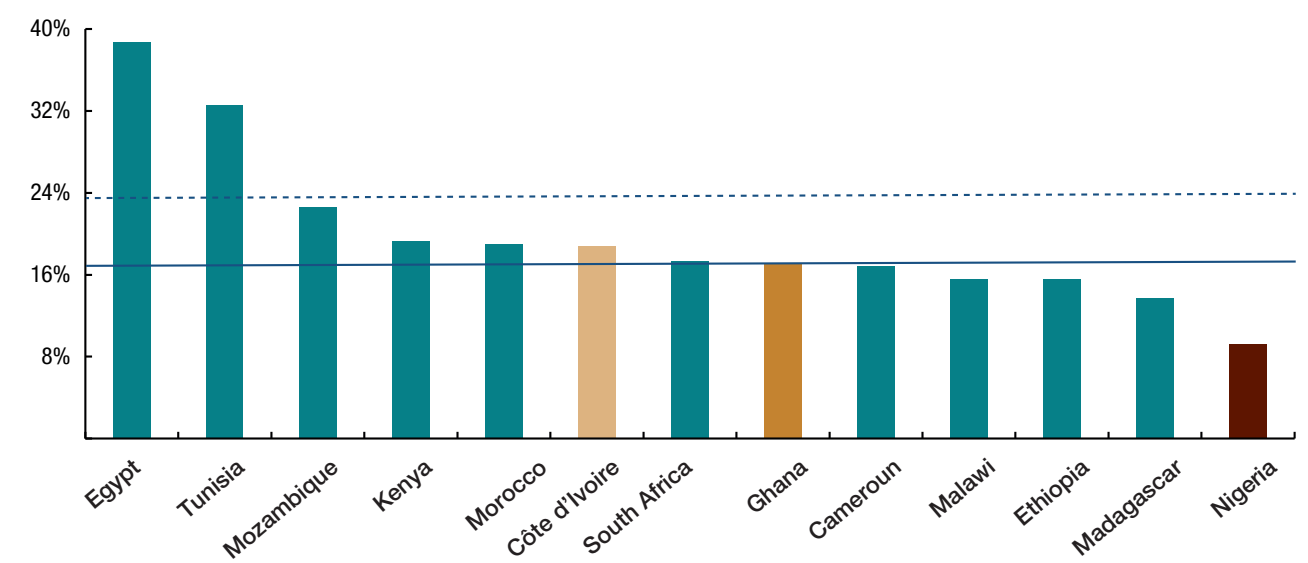

\section{Forward indicator*}

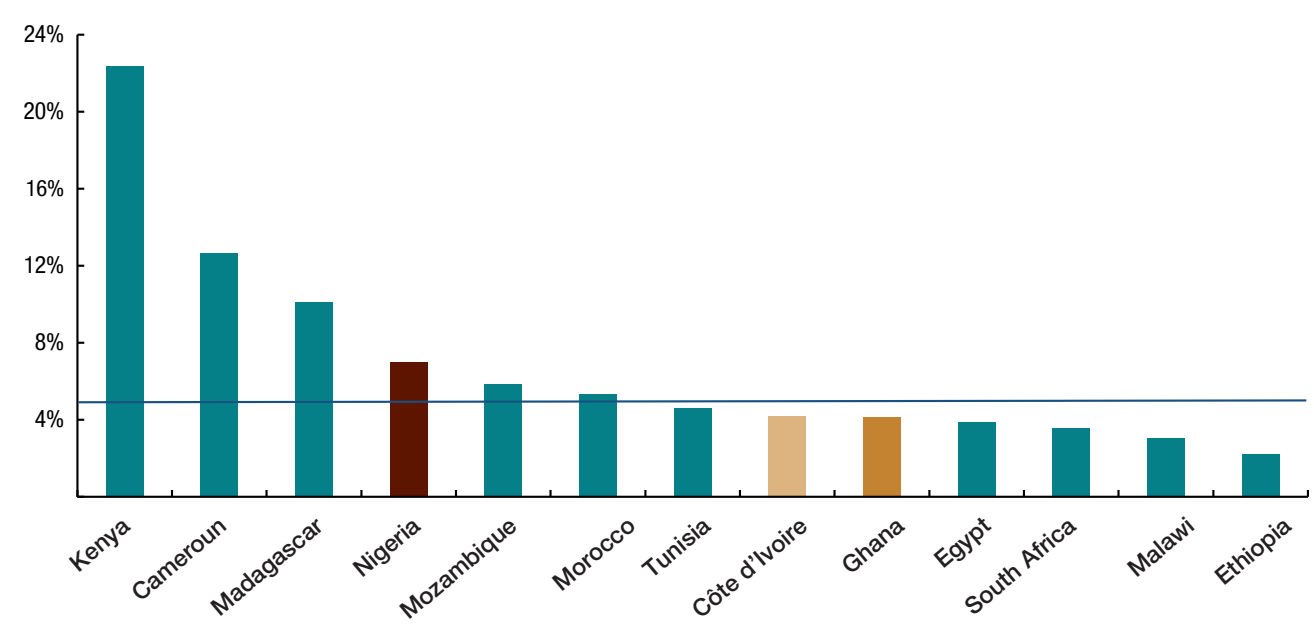

Notes:

* The Backward Indicator is the sum of the import value of intermediate products in exports divided by gross exports.

** The Forward Indicator is the sum of the export value used as inputs in partner countries' exports divided by gross exports.

For the Backward Indicator, the solid line indicates the average for developing countries, the dotted line for the developed countries.

For the Forward Indicator, the average is the same for both types of economies. The data covers 20 food products and 70 countries available in the Global Trade Analysis Project (GTAP) database, including 13 African countries. 


\section{POLICY AND FOOD SECURITY IMPLICATIONS}

Population and urbanisation are projected to continue growing strongly and the correlated growth and transformation of the food economy will accelerate. Current trends indicate that demand for processed and/or high value-added goods will grow fastest. Most of this growth will occur outside the agricultural sector in the food processing, distribution and marketing sectors. These activities will increasingly contribute to value added and job creation in urban and rural environments.

\section{Post-harvest segments of food value chains will experience the fastest growth.}

These transformations will increase the complexity of the food system and consequently that of food policy. Food value chains involve more actors in a larger geographical space. New activities also imply demand for new technological and commercial skills, infrastructure development, financing and co-ordination.

In terms of food security and nutrition policies, downstream segments of value chains must be included in the monitoring and analysis grid. Specific capacities must be developed to address the constraints facing vulnerable urban populations and to monitor new public health issues caused by changes in dietary habits.

\subsection{Connecting and co-ordinating food economy activities}

Markets have become the main source of food for West African households. The transition to a market economy is the source of profound changes in the food economy. New processing, transport and distribution activities are the segments of the food value chain expected to grow the most in coming decades. The Agricultural Growth in West Africa study (Hollinger and Staatz, 2015) reports higher income elasticity of demand exceeding 1.0 for a number of common processed goods (Figure 3.1), confirming that the demand

Figure 3.1

Income elasticities of demand in urban areas: Eight countries in West Africa*

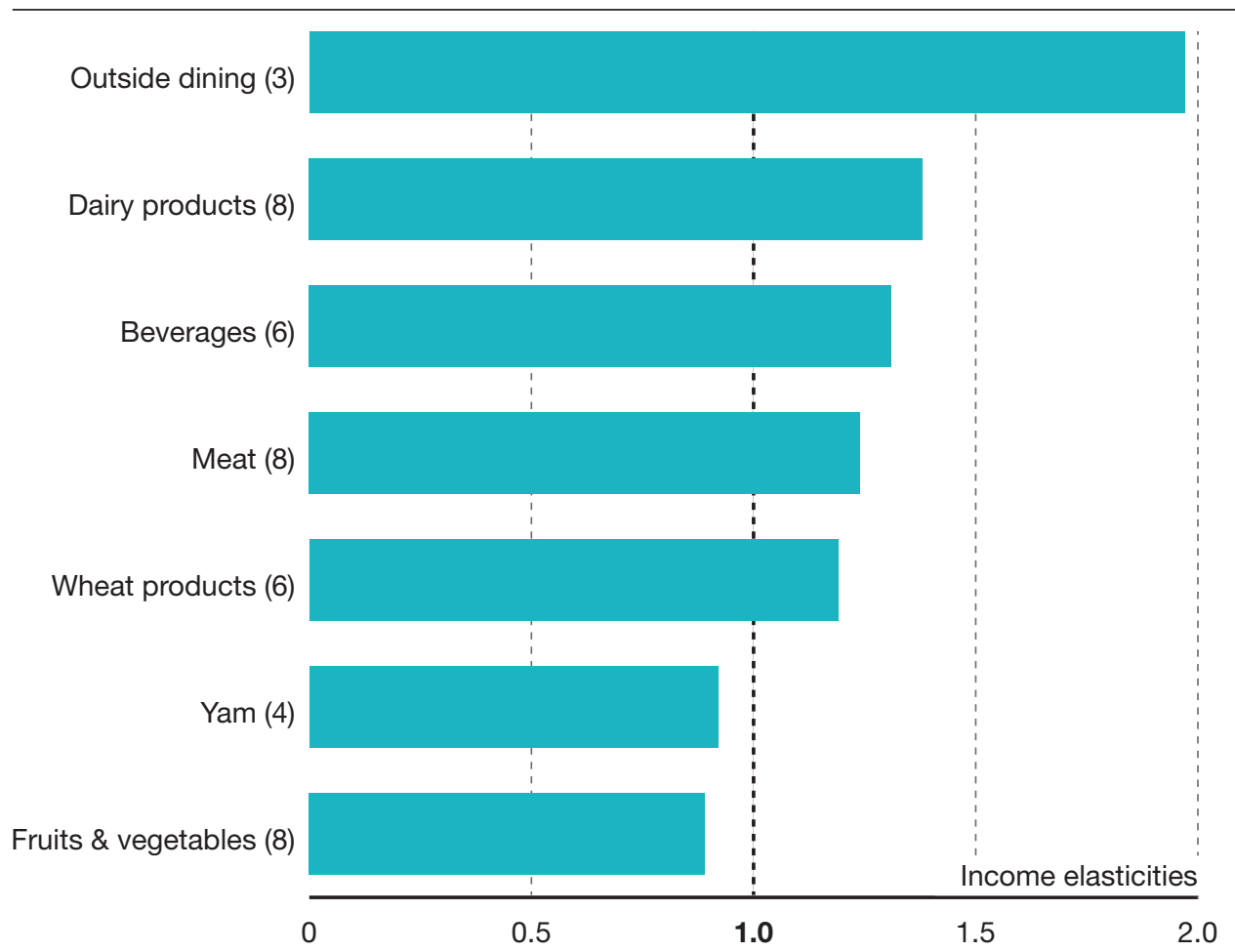

Note: * Burkina Faso, Côte d'Ivoire, Ghana, Mali, Niger, Nigeria, Senegal and Togo. The number of countries for which data on income elasticities were available is indicated in parentheses.

Source: Hollinger and Staatz, 2015 
for these products will grow faster than incomes. New actors and activities will enter the food economy to meet this demand. Today, they are co-ordinated through a combination of price mechanisms and network dynamics, interpreted as a system of relationships. The increase in the size of the food economy will require significant improvements in structuring value chains and strengthening connections between the various links. Efforts need to also be directed at facilitating the development of new activities and the availability and flow of information among the stakeholders involved.

\section{Development of the food economy will require significant improvements in structuring value chains.}

Increased demand and new food consumption habits are creating new markets for agricultural production. These demands translate into increased agricultural production and diversification towards new products. The transformations require, in particular, a re-evaluation of the commodity value chains that are deemed strategic. Food value chain development will also contribute to making progress in the agricultural sector through the technical demands these value chains set for the products and services they provide. A longer supply chain requires that producers and other stakeholders meet more stringent quality standards, particularly in terms of food safety. Often, agro-industries require very specific characteristics (shape, size, weight, texture, vitamin content, etc.). Standards and norms play a fundamental role in sharing information about products and production, processing and transport conditions. As such, they play an important part in organising and co ordinating value chain actors, in allowing for efficiency gains through reduced transaction costs and in facilitating the scaling-up of food production. The challenge is to devise appropriate standards for what largely remains a family-based agricultural system.

These changes also require new technical and business management skills. A real need exists for specialised and targeted education and vocational training, as well as appropriate consulting services to develop these new sectors of activity.

Value chain development is also taking place within a larger geographical space and requires the effective management of territories and their connections. Transportation, storage and communication infrastructures that facilitate mobility and trade help shape market sheds and trade networks. Road infrastructure plays a special structuring role in the organisation of trade, connecting production areas, and improving access to agricultural inputs and marketing.

Significant investment will be needed to support the development of the food economy. Stakeholders in the food system are essentially private actors with limited access to financing. Incentives and guarantee schemes and a supportive business climate are crucial for private investment to grow.

\section{Improving competitiveness, taking advantage of opportunities}

Food prices also reflect post-harvest activities. They contribute to an increase in the value of foods and added transaction costs. Today, food prices in West Africa are higher than elsewhere in the world at comparable income levels (Figure 3.2). 
Figure 3.2

Food price level index and per-capita GDP (2011)

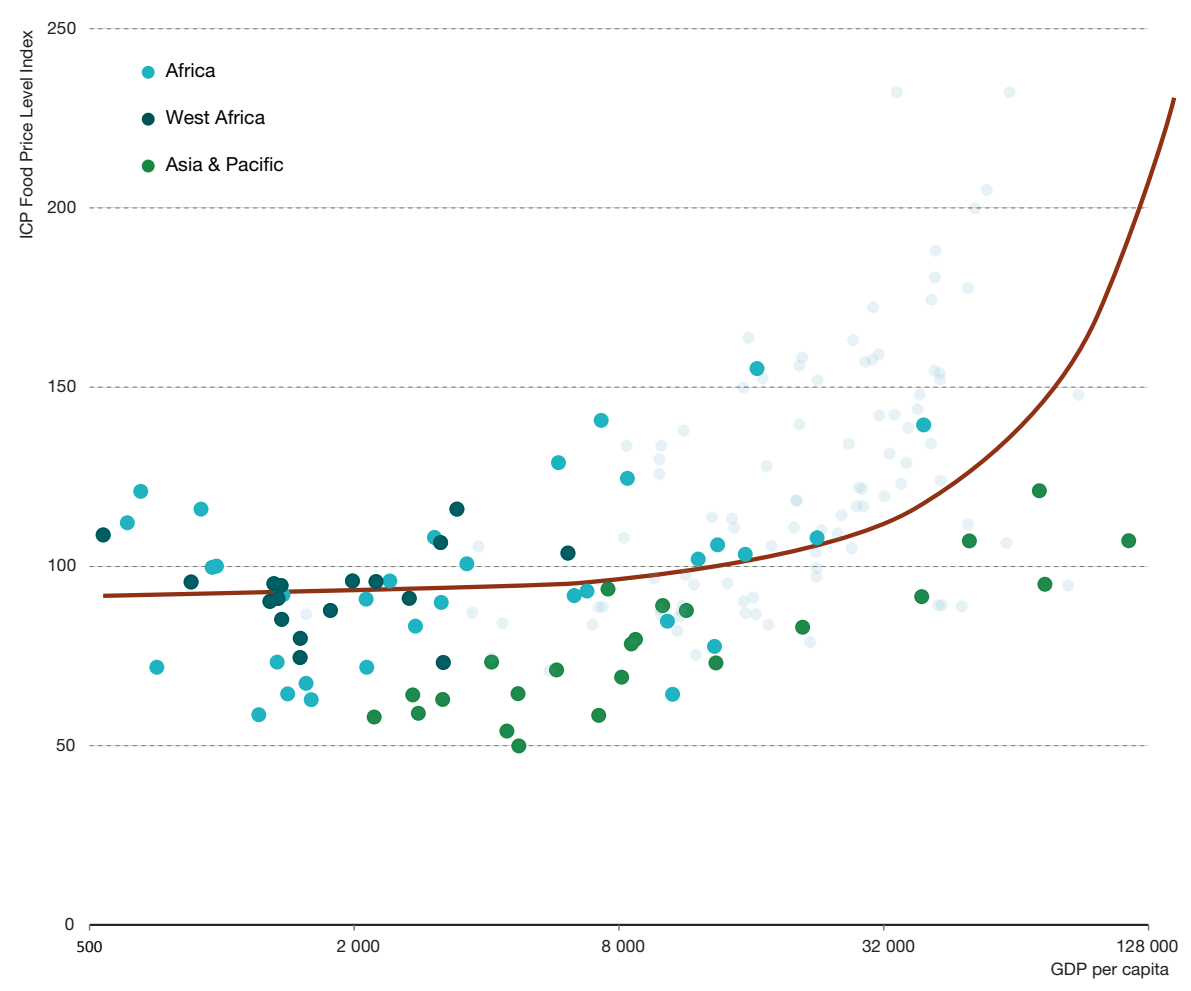

Sources: ICP 2011/World Bank, 2015 and authors'calculations

A better understanding of food price formation would help identify constraints and weaknesses along value chains that explain the high prices observed. Addressing these obstacles would reduce costs for households while maintaining producers' incomes. The limited competitiveness of local food chains, partly reflected in high prices, is an important development challenge. The various segments of food value chains offer significant job opportunities. A joint study by the World Bank and the International Labour Office showed that agribusiness is the main source of job creation in Senegal's informal sector (81\%) (Youth Employment Network and International Youth Foundation, 2009). The food economy plays a vital role in structural transformations, agricultural and rural development as well as income generation and job creation. In a context where consumers are demanding products of increasing value and quality, West African products are becoming increasingly exposed to foreign competition. This competition is not limited to final consumption goods; large processing plants are importing more and more raw materials (wheat and sorghum). Enhancing the competitiveness of West African products is a necessity and will depend on gains made at each stage of the value chain.

\subsection{Adapting food and nutrition security tools}

\section{Monitoring the entire food production process}

Changes in the food economy have important implications for food and nutrition security information systems and resilience mechanisms.

The well-functioning of agricultural production, food processing, transportation, storage and distribution processes, are essential to the stability of food supply. These processes are subject to obstacles and shocks that food crisis prevention mechanisms need to anticipate. Post-harvest activities and their monitoring also contribute to the resilience of the food system by mitigating shocks and by facilitating food stock management. 
Potential obstacles on downstream segments of the chain should explicitly be included in the analyses of contributing factors to food and nutrition security. Vulnerable populations are directly exposed to these activities as they spend more than one-third of their food budget on processed products and a large number live in cities and depend on markets for their food supply.

In addition, post-harvest activities also affect the final price of food products, which can influence households' resource allocation decisions. Any variation in food prices, whether due to an increase in raw material prices or processing, can erode households' purchasing power and impact food and nutrition security outcomes. Hence, including the main processed products in food price monitoring and early warning mechanisms is increasingly important.

\section{New public health challenges}

Changes in consumption habits are also creating new public health and nutrition challenges. Despite the observed reduction in malnutrition and improved food diversity, the nutritional transition underway also implies higher fat and refined sugar intakes, which can adversely affect public health. In sub-Saharan Africa, especially in cities, obesity and overweight rates as well as chronic non communicable diseases like diabetes and cardio-vascular disease are on the rise (FAO et al., 2013). In particular, the most vulnerable groups are faced with new food budget allocation decisions, constraining them to choose cheap but nutrient-poor calories. The 'triple burden of malnutrition', the simultaneous occurrence in the same country and even the same household, of undernourishment, nutrient deficiencies (not enough vitamins and minerals) and obesity, is currently a major concern for emerging economies.

Value chains, especially in food processing, offer numerous opportunities for improving the nutritional content of food. Food fortification (nutrient enrichment) programmes have already been successfully tested and implemented in West Africa. Vitamin and mineral deficiencies are a serious public health issue across the world and in sub-Saharan Africa in particular. In Africa, $44.4 \%$ of children under five are vitamin $\mathrm{A}^{7}$ deficient (WHO, 2009), while anaemia resulting from iron deficiency affects $67.6 \%$ of children under 5 and $47.5 \%$ of women between 15 and 50 years of age ${ }^{8}$ (WHO, 2008). Vitamin A-enriched oils, and iron- and folic acid-fortified wheat flour already exist in most West African countries. Some processed meals, such as gari in Benin, are enriched with protein-rich soy flour or vitamin A-rich palm oil. The fortification issue is all the more important considering that food processing can also result in the loss of nutrients. And lastly, distribution and retail activities can provide access

Box 3.1
Agro-industry and the environment
"Despite their important contribution to overall
and agricultural development, agroprocessing
industries can also give rise to undesirable
environmental side-effects. Left unchecked,
like any other industry, agro-industry can
create environmental pollution or hazards
in various ways: the discharge of organic or
hazardous wastes into water supplies; the
emission of dust or gases that affect air quality
and produce toxic substances; and the use of
dangerous machinery that can put the safety
and health of workers at risk. The seriousness
of the pollution problems created by agro-
industrial activity greatly varies, but it appears
that food transformation activities are generally
less energy-intensive and release less Co2
and metal residues than most other industrial
activities."
Source: Excerpt from "The State of Food and
Agriculture" (FA0, 1997))

Box 3.1

"Despite their important contribution to overall and agricultural development, agroprocessing industries can also give rise to undesirable environmental side-effects. Left unchecked, create environmental pollution or hazards in various ways: the discharge of organic or hazardous wastes into water supplies; the emission of dust or gases that affect air quality and produce toxic substances; and the use of dangerous machinery that can put the safety and health of workers at risk. The seriousness industrial activity greatly varies, but it appears that food transformation activities are generally less energy-intensive and release less C02 and metal residues than most other industria activities."

Agriculture" (FA0, 1997)) to a wider range of products and reach a greater number of consumers. There is a growing role for these branches of activity in dialogue and policy processes on food security issues.

Developing a capacity for analysis and prevention that is adapted to urban vulnerability Millions of urban dwellers live below the poverty line and face acute and/or chronic malnutrition. The vulnerability dynamics of this growing population is subject to specific characteristics, constraints and resources. Today, West Africa has almost as many urban

7 Indicated by a serum retinol level below the recommended threshold $(<0.7 \mu \mathrm{mole} / \mathrm{L})$.

8 For pregnant women, the prevalence rate is $57.1 \%$ (WHO, 2008). 
as rural residents, and almost as many food and nutrition insecure people in cities as in rural areas. In Mali, data from Multiple Indicator Cluster Surveys (MICS) show that 14\% of urban children under five are moderately or severely underweight, compared to $20 \%$ in rural areas; $18 \%$ are moderately or severely stunted compared to 31\%; 8\% moderately or severely wasted compared to $9 \%$; and $66 \%$ compared to $74 \%$ are anaemic (UNICEF et al, 2013). These prevalence rates are also markers of the

Constraints facing vulnerable urban populations need to be more specifically identified in information systems. nutritional status for the total population and highlight the scale of the challenge.

Early warning mechanisms are currently based on a geographical disaggregation of food and nutrition insecurity zones that do not systematically differentiate urban and rural environments. Consequently, certain monitoring indicators are sometimes inappropriate for urban areas. For example, the items recommended for monitoring households' livelihood assets (productive agricultural assets, agro-pastoral infrastructures, water, livestock fodder, pasture areas, etc.) make little sense in an urban setting. The food and nutrition security situation could be assessed more accurately if the constraints facing vulnerable urban populations were more specifically identified in information systems, thus paving the way for more appropriate responses in times of crisis.

\section{CONCLUSION}

Agro-industry, food marketing and agricultural transformations are inextricably linked and determine food security outcomes. The value chain approach reflects the realities of the food economy and its transformations. Monitoring the entire chain and improving its effectiveness is vital to ensure the availability, accessibility, quality and stability of food supplies. A multi-sectoral lens can help develop food security and nutrition policies that are better aligned with changes in the food economy and to improve resilience mechanisms.

The evolutions of the food economy in terms of demand, size and composition provide major opportunities for diversification and value creation. Family farms will remain the main source of food production in the years to come and need to integrate into value chains in order to benefit from emerging opportunities. Value chain development can facilitate the adjustment of supply to new demand and access to markets. Post-harvest activities also represent an important source of employment opportunities - in particular for women - and income creation. To generate the jobs, income and food required by a growing population, it is vital that the changes taking place within the food economy receive the same extensive support from policy makers and donors that agriculture benefits from. 


\section{REFERENCES}

African Development Bank (2014), Agribusiness in West Africa, West Africa Monitor Quarterly, issue 4, January 2014, African Development Bank (ADB), Abidjan, Côte d'Ivoire.

Bricas, N. and C. Tchamda (2015), Les profondes mutations des consommations alimentaires en Afrique, F. Mouton (ed.), Question de développement, Agence française de développement (AFD), Paris.

DPEE Senegal (2015), “Direction de la prévision et des études économiques - Ministère de l'économie et des finances du Sénégal" (Database) http://www.dpee.sn/-Structuredu-PIB,123-.html?lang=fr (accessed 7 September 2015).

FAO (2010), “Agricultural value chain development. Threat or opportunity for women's employment?", Gender and rural employment policy brief 4, FAO, Rome.

FAO (1997), "Les industries agroalimentaires et le développement économique", in La situation mondiale de l'alimentation et de l'agriculture, FAO, Rome.

FAO, IFAD and WFP (2013), The state of food insecurity in the World 2013: The multiple dimensions of food security, FAO, Rome.

FAOSTAT (2015), "Food and Agriculture Organization of the United Nations Statistics Division" (database). http://faostat3.fao.org/home/E (accessed on 7 September 2015).

Henriksen, L.F., L. Riisgaard, S. Ponte, F. Hartwich and P. Kormawa (2010), "Agro-food value chain interventions in Asia: A review and analysis of case studies", working document, United Nations Industrial Development Organization (UNIDO), Vienna.

Henson, S. and J. Cranfield (2009), “Building the political case for agroindustries and agribusiness in developing countries", in Agro-industries for development, pp. 10-46.

Hollinger, F. and J. Staatz (eds.) (2015), Agricultural growth in West Africa: Market and policy drivers. Food and Agricultural Organization of the United Nations (FAO), Rome.

ICP 2011 (2015), “International comparison program 2011 - World Bank" (Database) http://siteresources.worldbank.org/ICPEXT/Resources/ICP_2011.html (accessed 7 September 2015).

INSTAT (2013), “Enquête par grappes à indicateurs multiples 2010 Mali”, Institut national de la statistique (INSTAT), Cellule de planification et de statistique du secteur santé, développement social et promotion de la famille (CPS/SSDSPF), Rapport final, Bamako, Mali.

Moriconi-Ebrard, F., D. Harre and P. Heinrigs (2016), Urbanisation dynamics in West Africa 1950-2010, Africapolis - 2015, West African Studies, OECD Publishing, Paris, http://dx.doi.org/10.1787/9789264252233-en.

OECD (2016), GVC participation in the agriculture and food sectors, OECD Publishing, Paris (forthcoming).

OECD (2015), "Africapolis list and population of West African urban agglomerations 1950-2010", West African statistics (database), http://stats.oecd.org/ (accessed on 20 April 2016). 
OECD (2013), Settlement, market and food security, West African Studies, OECD Publishing, Paris, http://dx.doi.org/10.1787/9789264187443-en.

Paillard, S., S. Treyer and B. Dorin (2010), Agrimonde. Scénarios et défis pour nourrir le monde en 2050, Matière à débattre et à décider, Editions Quae, Paris.

Tschirley, D., T. Reardon, M. Dolislager and J. Snyder (2014), “The rise of a middle class in East and Southern Africa: Implications for food system transformation", Journal of International Development, vol. 27, no 5, pp. 628-646.

WHO (2009), Global prevalence of vitamin A deficiency in populations at risk 1995-2005, WHO Global database on vitamin A deficiency, WHO, Geneva.

WHO (2008), Worldwide prevalence of anaemia 1993-2005: WHO global database on anaemia, World Health Organisation (WHO), Geneva.

World Bank (2015), “Global consumption database” (database), http://datatopics.worldbank.org/consumption/ (accessed on 20 April 2016).

Youth Employment Network and International Youth Foundation (2009), Private sector demand for youth labour in Ghana and Senegal: Ghana and Senegal study findings, World Bank, Washington DC and ILO, Geneva.

UNSD (2015), “United Nations Statistics Division - National Accounts Statistics: Main Aggregates and Detailed Tables" (Database) http://unstats.un.org/unsd/ nationalaccount/madt.asp?SB=1\&\#SBG (accessed 7 September 2015). 